Sultan Qaboos University Journal of Arts \& Social Sciences

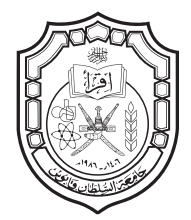

جامعة السلطان قابوس الإدابعاب

مجلة الآداب والعلوم الاجتمأعية

\title{
Community Translation in the Sultanate of Oman: A Soft Force in the Fight against COVID-19
}

\begin{tabular}{c}
\hline Musallam Al-Ma'ani \\
\hline Associate Professor \\
English Language and Literature Department \\
College of Arts and Social Sciences \\
Sultan Qaboos University \\
musallam@squ.edu.om
\end{tabular}

\begin{tabular}{c}
\hline Abdullah Said Al-Ajmi \\
\hline MA Translation Program \\
English Language and Literature Department \\
College of Arts and Social Sciences \\
Sultan Qaboos University \\
asaajmi@diwan.gov.om
\end{tabular}

Sara Ali Al-Ajmi

MA Translation Program

English Language and Literature Department

College of Arts and Social Sciences

Sultan Qaboos University

saoajmi@rca.gov.om 


\title{
Community Translation in the Sultanate of Oman: "A Soft Force" in the Fight against COVID-19
}

\author{
Musallam Al-Ma'ani, Abdullah Said Al-Ajmi and Sara Ali Al-Ajmi
}

Abstract:

Translation, in modern Oman, serves as an essential means of communication between the Arabicspeaking Omanis and other individuals of smaller linguistic and ethnic communities working or residing in the country. The purpose of translation in such situations is to empower linguistically disempowered individuals within Oman and ensure that they are adequately informed and that they actively participate in the country's development. Yet, there have been very few studies that deal specifically with community translation in Oman and in the wider Arab world. The lack of a translation governing body and Omani translation scholars' tendency to focus on literary and technical translation in Oman are some of the factors that have kept community translation very much on the margins of translation. The aim of this contribution, therefore, is to address some of the issues pertaining to community translation in the Sultanate of Oman. In particular, it focuses on the long-standing relationship between translation and communication within Oman and how translation plays a pivotal role in the development of the country, given the fact that Oman, like other countries in the Arabian Peninsula, relies to a great extent on skilled expatriate workforce in various fields. In particular, this contribution investigates the role community translation has played in the fight against COVID-19 in the Sultanate of Oman. The effects of this pandemic are serious particularly in a country where around $40 \%$ of its population comes from different parts of the world and the majority of whom do not speak Arabic, the official language of the country, nor do they speak or read English, the language of business in Oman. During such times, community translation becomes crucial.

Keywords: Communication; Community Translation; COVID-19; Culture; Oman.

\section{الترجمة المجتمعية في سلطنة عمان: قوة ناعمة في مواجهة فيروس كورونا}

مسلم المعني، وعبدالله بن سعيد العجمي، وسارة بنت علي العجمي

الملخص:

تعد الترجمة، في سلطنة عمان اليوم، وسيلة تواصل أساسية بين العمانين المتحدثين باللغة العربية والأفراد الآخرين ممن يعملون أو

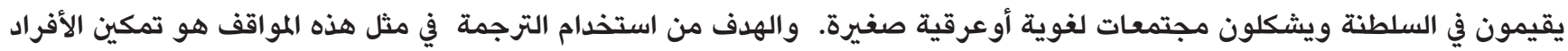

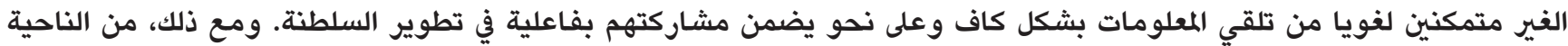

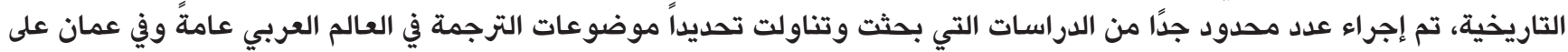

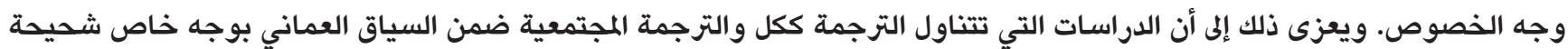

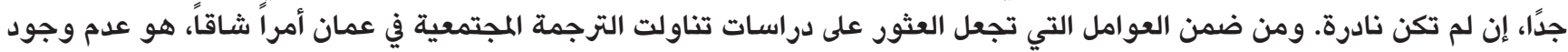

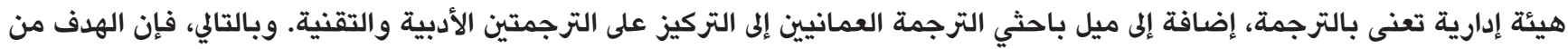

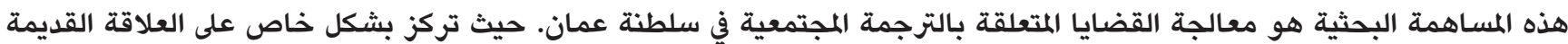

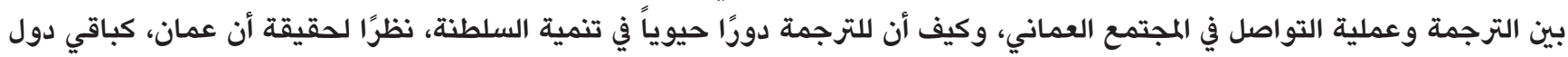

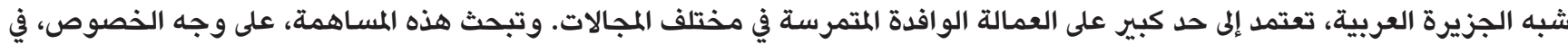

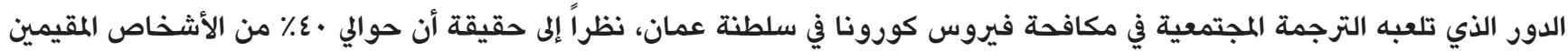

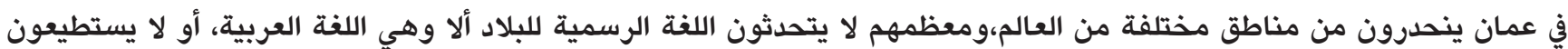
التواصل باللغة الإنجليزية لغة الأعمال في السلطنة.

الكلمات المفتاحية: التواصل، الترجمة المجتمعية، فيروس كورونا، الثقافة، عمان. 


\section{Introduction}

The world has been recently struck by an unprecedented global crisis, the outbreak of the corona virus (COVID-19 pandemic), that has detrimental effect on almost every country, rendering all walks of daily life people accustomed to powerless and ineffective. As the health services come to fore of the battle against the virus, it has nevertheless proven to be incapable, at least in the short term, of finding a cure against this virus. Countries have, therefore, resorted to various means, in which translation occupies a front position, of contending against the virus, with an aim of keeping its effect on people at a minimum.

Translation, hence, comes to play a role. In a globalized world, where people move to different countries for work, taking host countries as their place of residence, governments have found themselves obliged, in their handling of COVID-19, to communicate without delaying momentarily to all people, citizens or residents, in large or small numbers, living within the country. As an interlingual and intercultural activity, translation has proven to be one of the most powerful soft forces, along with other media modes, that countries have deployed. Countries devote serious effort to ensure that measures are taken beforehand to prevent, not to cure, the infection and spread of COVID-19. People, regardless of their social status, need to be informed ahead of time about COVID-19, its causes and how it spreads. As precautionary measures are of utmost importance, the communication of updates and notifications, issued by the competent authorities to people, have become an essential requirement for prevention.

Historically, translation has been carried out for various purposes. Al Ma'ani (2018: 36) considers translation "as an intercultural apparatus through which innovations and inventions are passed from one culture to another, creating a platform of interdisciplinary nature in the host culture into which translation is carried out". As an interlingual activity, translation continues to play a fundamental role in helping overcome the language barrier. The social significance of translation within this interlinguality lies in the fact that it can be used as one of the means to equip people with necessary information they need as part of a rapport that has become established as a result of their residence within the country.

Community translation (CT) is one of the subjects that has recently received attention by translation scholars because of its significance in studying the relationship between translation and the community. Niska (2002) defines CT as "written translation of mainly informative text, addressed by authorities or institutions to people who do not understand texts in the language of the text producer" (p.135). Taibi and Ozolins (2016: 8) consider CT as "a service offered at a national or local level to ensure that the members of multilingual societies have access to information and active participation" In other words, it is a service often offered by the authorities of a country to smaller communities, but there are cases where smaller communities also produce texts that could be useful to the larger community in the country. The whole purpose of providing translation within this context "to ensure communication with all citizens and permit their participation and, therefore, empowerment" (Taibi, 2011: 214-15). Perhaps what distinguishes $\mathrm{CT}$ form other types of translation is its predetermined constituents. CT generally involves four basic ingredients: (1) producers, normally of an authoritative nature in a country, of texts; (2) community texts; (3) the community itself, targeted audience; and (4) community translators.

However, different terms have been used to refer to CT by scholars depending on the place in which it is practiced. O'Hagan (2013: 12) says that Australian and American authors use the term "community translation" in association with "community interpreting" to refer to "the written translation of public information for an immigrant population". On the other hand, Schuster and Olmos (2018: 733) lay stress on "community interpreting" and "public service interpreting" which can be used interchangeably, since they "take place mainly in public sector service provision interactions". Countries, to which people from other nations come and dwell temporarily or permanently, find themselves morally compelled to address and communicate with such people, during state of affairs like the COVID-19 one the world goes through, in a language which does not always seem to be the official one of the country, making it an obligatory step to translate to one or more foreign languages, especially during state of affairs, like the corona pandemic nowadays, in which decisive change is impending.

Community, according to Tönnies (2004), can be seen as an organic natural kind having systematic coordination of its parts as represented by social. Individuals composing such groups are bound together by the sense of belonging, brought into existenceon everyday contacts covering the whole 
range of human activities. Talcott Parsons defines it as "collectivity the members of which share a common territorial area as their base of operation for daily activities" (Craig et al, 2014). In Merriam Webster's online dictionary, community is defined as "a group of people who live in the same area (such as a city, town, or neighbourhood) or a group of people who have the same interests, religion, race, etc.".

When a group of people forms a community in another country, it is arranged as a small unified body of individuals living within a larger host society whose language and culture are far apart, the common interests of such a community does not necessarily include people with similar racial, religious and social backgrounds, nor does it include individuals who resemble, in every relevant respect, the same culture or a distinct entity with common customary beliefs, social forms and material traits back home in their original country. However, language can be conceived as a harmonious common ground among such a community. Language is the basis of their mutual interests and is enclosed closely in culture (Al-Belushi et al. 2018). That is why translators need to think carefully about the socio-linguistic and socio-cultural factors when dealing with to other communities.

Here, community texts refer to texts generated either by the larger community (society) represented by the host country or by smaller communities (linguistic or ethnic communities within a society, local communities, religious group, etc.). However, this is not always the case with $\mathrm{CT}$, since it is not a oneway activity. The direction of community translation can be in both ways. That is, smaller communities may also communicate with the larger communities through CT. Štefková and Bossaert (2019) state that CT enables residents to express themselves and their needs of services to the government. Taibi (2011) argues that community texts may include documents from smaller communities' countries or place of origin. Community texts cover printed publications made available for public dissemination by the concerned bodies of the government, but not all government produced publications fall under the term 'community text'. Governments normally have a series of intricate and complicated ways of running a country. This means various departments are brought into existence to deal with matters which are partly or totally unlike in nature, form or specialization and produce intricately combined material for publication. The information is not always necessarily produced, albeit being available in public domains, for the direct use of citizens and residents.

Since CT requires much time, effort and attention, community translators are required to be sensitive to issues like language and culture. As they are supposed to be linguistically competent, translatorsare likewise are supposed to be culturally conversant with the culture(s) of the community to whom translation is carried out, capable of discovering minute crosslinguistic and cross-cultural differences between the source language $(\mathrm{SL}) /$ source culture $(\mathrm{SC})$ and the target language (TL)/target culture (TC), because "translation is not made in vacuum. It is produced for a specific purpose in a specific manner" (Al Ma'ani, 2019: 144). Since they are not only linguistically different but culturally far apart as well, CT audiences are invariably not acquainted with the SL and SC. While it is generally accepted that the CT audience may rely on dictionaries to understand the meaning of words, and particularly bilingual dictionaries, the use of dictionaries, monolingual or bilingual, does not always produce good results because translators have both the linguistic and cultural knowledge and use dictionaries as "a stimulus to the process of refining meaning and selecting an appropriate rendering" (Fraser 1993: 135). Because CT translators deal with various disciplines, they need to be familiar with a full range of areas of interest that the community needs; and even when there are institutions normally responsible for providing a certain service, there is not a regular pattern that conforms to certain types of texts which translators need to specialize in. That is why community translators need to have a basic knowledge of the subject matter, familiarity with the relevant terminology and competence in TL and TC.

\section{Oman and the COVID-19 Outbreak}

Studies which investigate translation in relation to community in Oman are scarce and are, generally speaking, limited in degree or extent. The reason is that Oman as a modern state is only a 50 -year-old country, started when the late Sultan Qaboos assumed power in 1970. The progressive development taking place in all walks of life-educational, social, economic, and administrative meant that the county, like other countries in the region, relies on foreign nationals coming from other countries to perform a great number of duties that locals do not have the capacity to do. This was especially the case during the early years of development. That is why, although Arabic is the official language of the country, English in modern Oman, according to Al Ma'ani and Al Kindi (2017: 7), is 
used to a great extent in various sectors, especially by those working in engineering, oil and gas, and most of the business sector.

However, in the Middle East, especially in the Gulf Cooperation Council (GCC) countries, the concept of community differs from that used in other countries like the USA, UK, Australia, etc. Whereas, in such societies, members of different communities take part in the orderly arrangements between the country and those living in it, their partaking is stipulated in the constitution or implicitly becomes a part of the society through the law of the country. In the Middle East, the concept is somehow different. A citizen is a native or naturalized person and a member of the state, whereas a resident is a person who has migrated to the country and lived there for some length of time and whose status is determined by an employer-employee relationship which is a kind of renewable temporary stay mandated by the labor law of the country.

According to population census at the National Centre for Statistics and Information (NCSI) website, https:// www.ncsi.gov.om, the population of Oman reached $4,437,083$ with $1,920,815$ non-Omanis, constituting $41.50 \%$ of the total population (see appendix 1 ). Most of the expatriates are non-Arabs, and, since they live in Oman, where Arabic is the official language of the government apparatus, they need to have access to information published in Arabic. Expatriates in Oman are mainly concentrated in the private sector, where official figures show that $70 \%$ of the population of the private sector manpower are expatriates. Most of the expatriates have taken Oman as a place of residence or a place of work. Some of their family members are either born in Oman or have moved to Oman when they were very young. However, a high percentage of them do not speak, or speak little, Arabic, because they either go to community schools of their own or go to English speaking schools, or other foreign nonArabic schools. According to Oman's Government Communication Department data (see appendix 2), the most top 10 communities live in Oman include those coming from India, Bangladesh, Pakistan, the Philippines, Sri Lanka and Ethiopia, and speak their own languages.

The inclusion ofa number of communities of people of different races and cultures causes confusion and makes it a difficult task for the host country, like Oman, to deal with, especially during such crucial times as COVID-19. Taibi and Ozolins (2016:97) argue that small communities living in a larger one present manifold challenges, especially with regard to communication, as a result of their diversity and their different communication needs, because "in emergency humanitarian situations, there is practically no time for planning and preparation" to meet the diverse linguistic requirements of the different ethnic groups being hosted in a country. Therefore, in circumstances, like the current outbreak of COVID-19, Oman, like other countries in the region, finds itself obliged to reach the communities which should have no enclosing or confining barriers that interfere with or slow the progress of communication between the host country and communities.

However, as a host country, Oman devotes serious effort to approach communities through a whole host of options, including translation, to achieve planned policies. As CT is indispensable, Chakhachiro (2017:4) states that it is the duty of the host country to "communicating pertinent messages to [the smaller communities living therewithin] through translated materials that are linguistically accessible and culturally appropriate". That is why shortly after the outbreak of the virus in Oman, a Supreme Committee to deal with COVID-19 was formed and was ready and quick to act as the situation demands. The Supreme Committee has been set up to make Oman's total work done to address COVID-19 a coherent whole and is delegated to consider, investigate, take action on, or report on matters related to COVID-19 in Oman, and to ensure that the public can cognize the government messages and advice in this regard.

\section{Community Translation on the Frontlines}

$\mathrm{CT}$ finds itself in the vanguard of the government action to deal with COVID-19. Emplaced as one of indispensable means to fight COVID-19, CT becomes a soft force with a very stately presence in the communication world in its manifold forms. Before the outbreak of COVID-19, CT was not conceived vividly in the GCC since "[n]o significant measures have been taken to facilitate communication between migrant workers and public services, probably because it is unwittingly assumed that everybody can functionally communicate in English" (Taibi, 2014: 57). However, in its handling of COVID-19, the Omani government nowadays uses a plethora of tools to communicate public notices originally written in Arabic along with translation into English and some other languages to communities living in Oman. CT can be found in social media platforms, radio stations, TV channels, and official websites, which are all set apart to the service 
of people during COVID-19 pandemic.

When the world experienced a sudden rise in the incidence of COVID-19 outbreak, the Omani government, represented by the Ministry of Information (OMANINFO), launched a campaign in the form of an official twitter account, Oman VS Covid19 (@OmanVSCovid19), to send with promptness updates and notifications written in Arabic along with English translations to communities living in Oman (see appendix 3). OMANINFO website, http:// omaninfo.om/english, includes ongoing news about the virus, awareness and audio bulletins.

Statements issued by the Omani Ministry of Health $(\mathrm{OMoH})$ are aired every day in Arabic along with their English translation, targeting non-Arabic speaking members of other communities (a sample is given in Appendix 4). The motive of English target texts is to impart information to non-Arabic speakers about COVID-19 new cases, recovered cases, and some health tips on this pandemic, with an aim not to leave a point of elusion for all those living in Oman. Realizing its moral and legal accountability in the eyes of the society and communities, $\mathrm{OMoH}$ serves as the first line of defence by not being parsimonious in providing free treatment for all COVID-19 cases and promoting awareness as a preventive action. It is the latter the $\mathrm{OMoH}$ has relied on to curb the spread of the virus, through a highly concentrated campaign taking $\mathrm{CT}$ as a leading tool to reach communities in Oman.

In addition, CT has been evident in Oman's TV channels and radio stations, devoted to convey quality information to all citizens and residents in Oman. Statements and notices issued by governmental bodies on COVID-19 are aired in both Arabic and English, either through the official Oman TV channel or through other commercial radio stations. For instance, $\mathrm{Hi} \mathrm{FM}$ radio station broadcasts a translated daily five-minute public notification in the morning to inform non-Arabic speakers about Oman's latest updates on COVID-19. Merge FM also broadcasts, on a daily basis, measures to be taken beforehand to prevent infection of COVID-19 and other steps taken by the Royal Oman Police (ROP).

As part of the government's serious attempts to communicate public notices to members of nonArabic speaking communities living in the country, $C T$ is once again spread out to serve community in the face of COVID-19. A sound cloud account has been set apart by the Government Communication Department to broadcast audio bulletins covering current information on COVID-19 (see appendix 5). As
Arabic is the official language of the country, the brief public notices are translated into a pool of more than twenty languages including Urdu, Tagalog, Bangla, English, Hindi, Swahili, Kimzari, Baluchi and Sinhala.

Furthermore, CT has been deployed over a broad range of channels including official websites of some government departments. Already available official websites of some departments have been devoted with deep solemnity to serving communities through translating notices issued by these departments on COVID-19. For instance, eOMoH daily statements on COVID-19 are made available online on $\mathrm{OMoH}$ website, www.moh.gov.om, releasing updates in Arabic along with translation in English. Once logged in, there is on the top of the webpage of $\mathrm{OMoH}$ website a black label with an alert entitled "Corona virus Disease (COVID-19) Read more". Clicking on the link, it opens a new webpage with information about COVID-19. Besides, at the bottom of the page, there is a call center number, provided for those coming from outside Oman. There is also another audio provision in the website for those who cannot read the information. They can highlight the written text and an icon called "listen" will read the text. the ROP website, http://evisa.rop.gov.om, also includes a wide range of services, which are of great significance to members of communities living in Oman, such as those related to visas, residence cards and driving licenses (see appendix 6). Although the information is made available in Arabic, an English translation is provided for all ROP statements on these services.

Similarly, CT is manifest in the news released by Omani News Agency (ONA). The latest news on COVID-19 is published in the form of breaking news, through a mobile application. To follow the latest and breaking news of COVID-19 in Oman and elsewhere in the world, members of communities living in Oman can download the application and receive COVID-19 updates via messages. The application allows nonArabic speaking subscribers to follow news and updates in English as well. Further, family members can access ONA's website, www.Omannews.gov.om, from anywhere in the world, allowing them to follow the latest developments taking place in Oman.

As part of its effort to support other departments in Oman during COVID-19, the website of the Public Authority for Consumer Protection (PACP), http:// pacp.gov.om/, has also made use of CT. Its site contains all news and updates regarding PACP to reassure citizens and residents, Omanis and non-Omanis, about price stability and the crackdown on those violating 
consumers' protection laws in Oman, sending strong signals to people not to have over powering fright and to companies not to increase prices. Although Arabic serves as the SL for PACP updates and notifications, English translation is provided as well.

\section{Conclusion}

During crises, CT provides a significant service as it gives various communities within a society an ingress to information which they cannot at all times be thoroughly familiar with unless being translated into their own language or a language they can understand, like English, for instance. CT is a social enterprise tasked with the role of facilitating interaction in a society where the interaction of all individuals, Omanis and non-Omanis, Arabic and non-Arabic speaking residents in our case, means reliance on translation for specific interlingual and intercultural purposes. Its role can be seen with a fleeting view in the way Oman has dealt with the current global COVID-19 pandemic. When translation becomes a tool to serve, benefit and ensure the rights of small communities living within one larger host community, the Omani government has been able to discharge its duties through this soft force, i.e. CT.

As governments attempt to keep their communities informed and updated, CT's role in this COVID-19 pandemic transcends its traditional scope that falls within the confines of the linguistic and cultural bosom. Governments, guided by their endeavors to fight COVID-19, find it very important to reach out to people living in their countries through some untraditional tools, including CT which has no longer been kept within the walls of translation offices nor bound up with physical proximity, but rather has become a soft force that serves communities in weal and woe in the best possible way, helping governments to gain confidence and trust of the communities they govern.

Appendix 1: NCSI. (2020, May 5). Population Clock. Retrieved from https://www.ncsi.gov.om/Pages/ NCSI.aspx. (figure 1)

Appendix 2: Government Communication Department. (2020, May 2). Manual of Non-Arabic Speakers Residing in Oman. Retrieved from Together@ gsc.gov.om, p.4. (figure 2)

Appendix 3:GovernmentCommunication Department. (2020, May 3). @Oman VS Covid19. Retrieved from
(https://twitter.com/OmanVSCovid19). (figure 3)

Appendix 4: OMoH. (2020, May 3). Health Statements. Retrieved from https://www.moh. gov.om/en/announcements? p_p_id $=122$ INSTANCE_y5HDFOlyuBI2\&p_p_lifecycle $=0 \& p_{-} p_{-}$

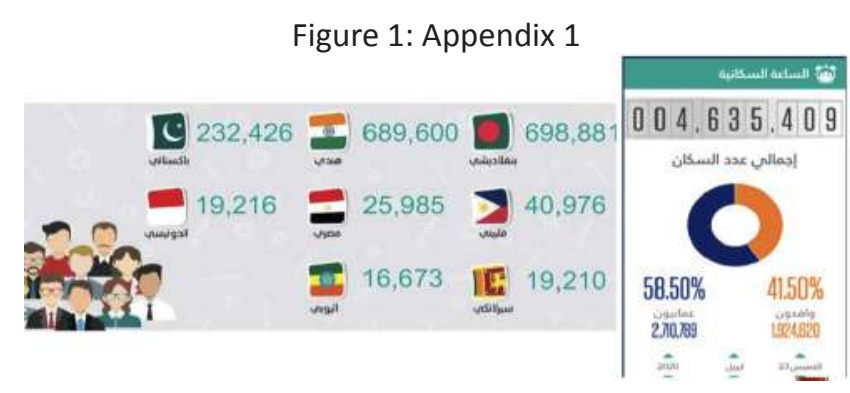

Figure 2: Appendix 2

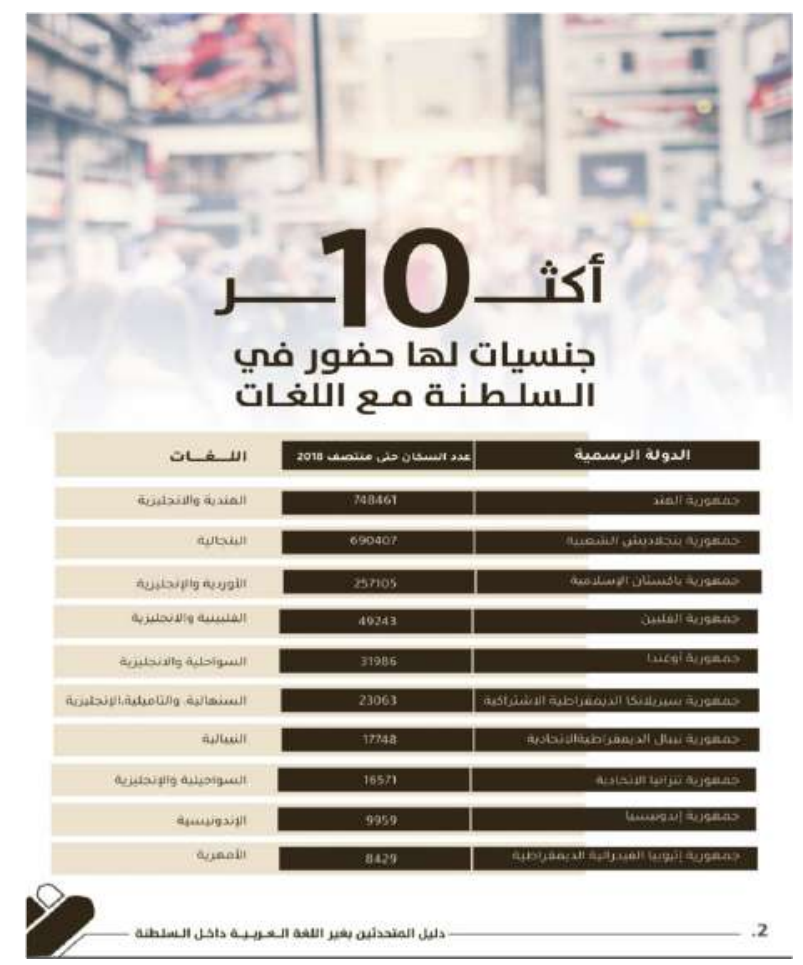

Figure 3: Appendix 3

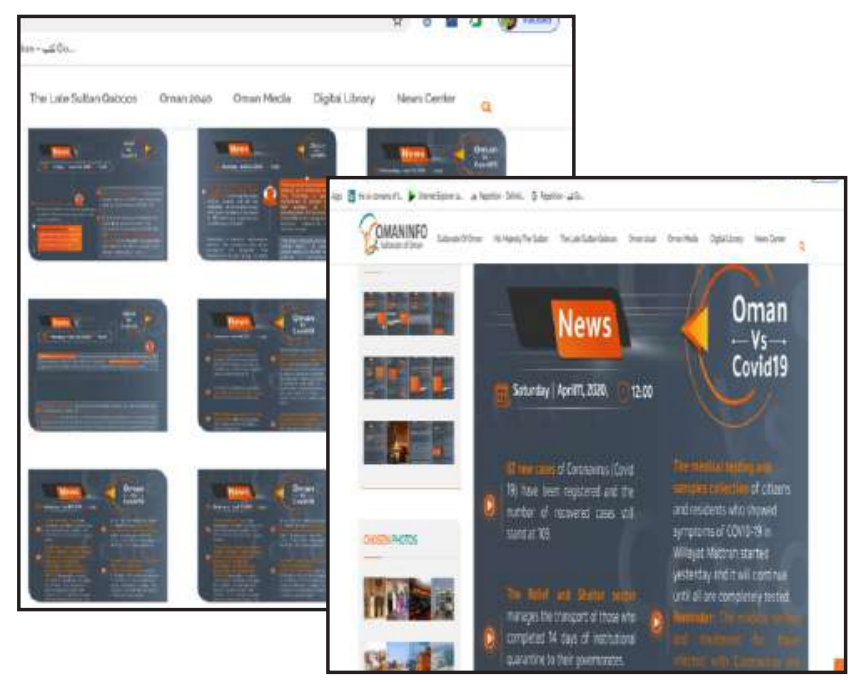


Figure 4: Appendix 4

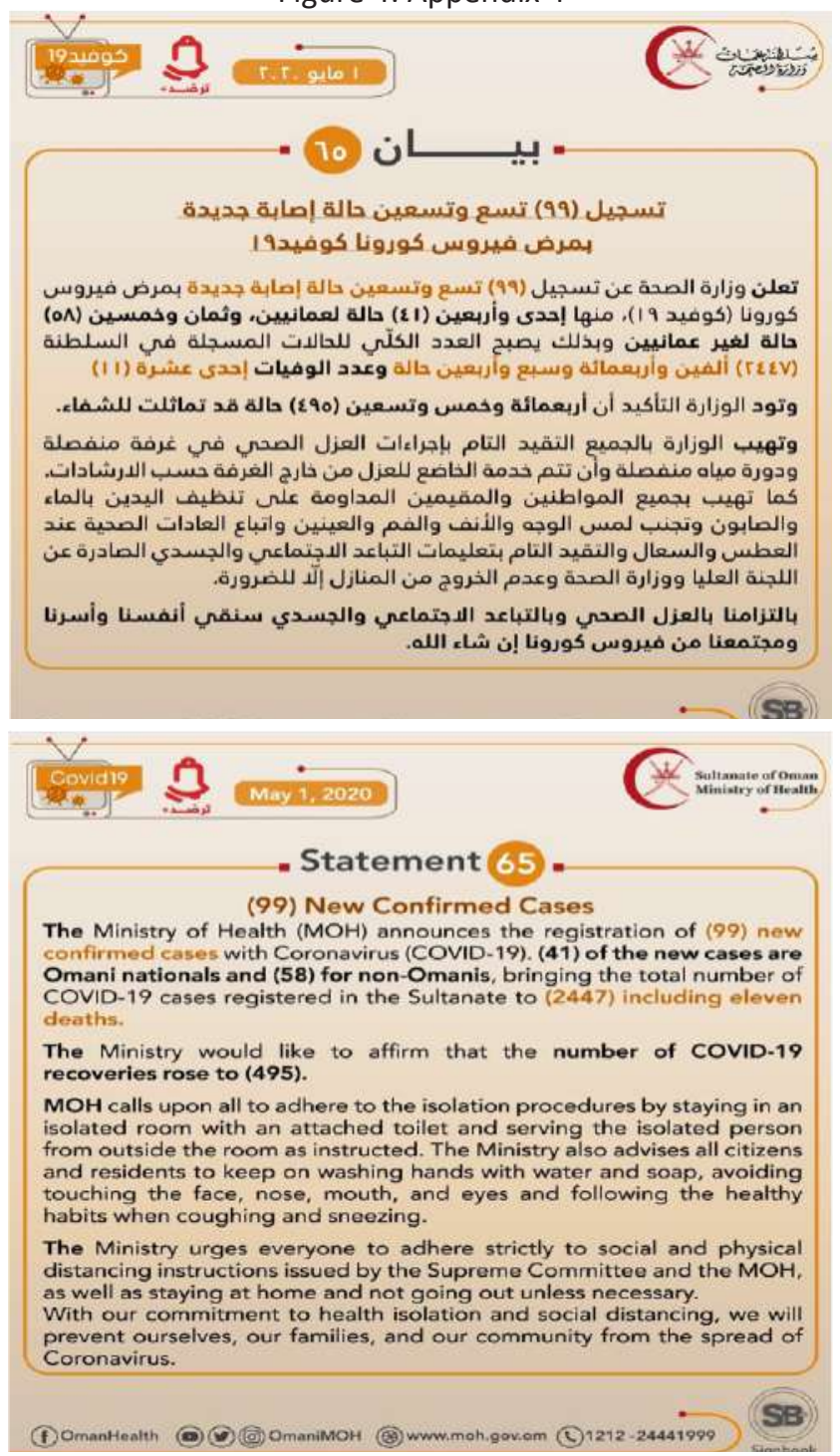

Figure 5: Appendix 5

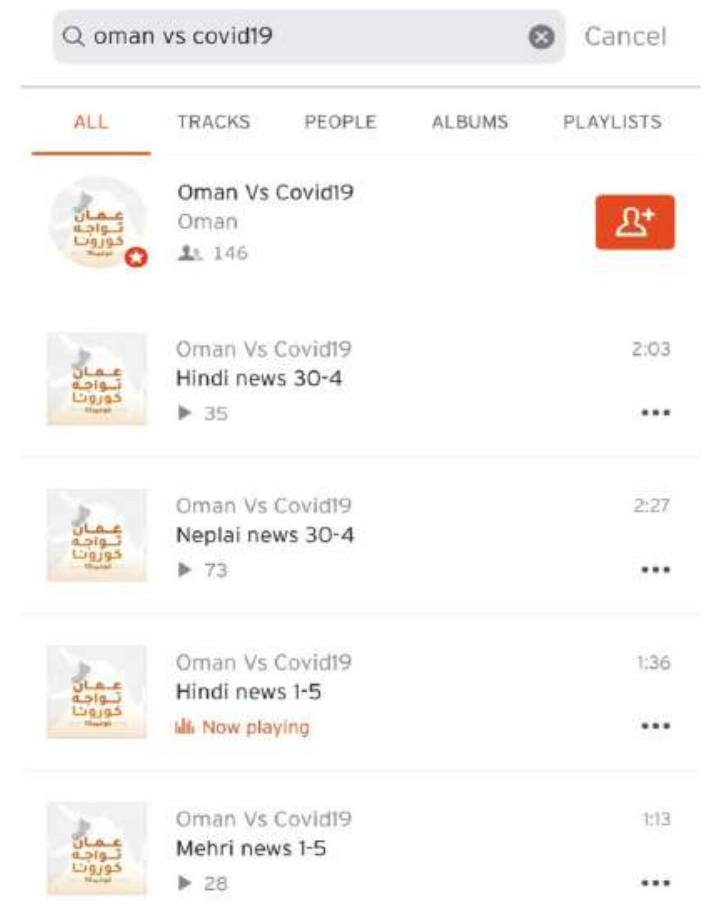

state $=$ normal $\& p_{-} p_{-}$mode $=$view $\& p_{-} p_{-}$col_ id=column-2\&p_p_col_count=2\&p_r_p_564233524_ resetCur=true \&p_r_p_564233524_categoryld= (figure 4)

Appendix 5:GovernmentCommunicationDepartment. (2020, May 3). Oman Vs Covid-19. Retrieved from https://soundcloud.com/search?q=oman\%20vs\%20 covid19\&query_urn=soundcloud\%3Asearch-autoc omplete\%3A42c4409176bd4eb7acf9d8b124cf632d (figure 5)

Appendix 6: ROP. (2020, May 3). ROP COVID19 Data. Retrieved from https://twitter.com/ RoyalOmanPolice?ref_src=twsrc\%5Egoogle\%7Ctwca mp\%5Eserp\%7Ctwgr\%5Eauthor (figure 6)

\section{References}

Al-Belushi, M., Al-Mashani, M., Al-Ma'ani, M. (2018). Oman State \& People. College of Arts \& Social Sciences, Sultan Qaboos University.

Al-Ma'ani, M. (2019). A Semantic Approach to Translating State Propositions in English-Arabic Technical Context (English-Arabic). In S. Faiq (Ed.), Arabic Translation Across Discourse(143-156). London and New York: Routledge.

Al-Ma'ani, M. (2018). The Role of Translation in forming Interdisciplinarity in Arab Mediaeval Times: A Historiographical Review. In M. Al Suqri\& et al (Eds.), Promoting Interdisciplinarity in Knowledge Generation and Problem Solving (29-37). USA: IGI.

Al-Ma'ani, M. \& Al Kindi, G. (2017). Translation and EFL in Oman. Journal of Arts \& Social Sciences, 7, 2130.

Chakhachiro, R. (2017). Communicating through Translation with Arab Migrants in Australia. Arab World English Journal for Translation \& Literary Studies, 1(4),2-24. Retrieved from https://cutt.ly/3ykN5x2.

Craig J. \& Forsyth, H. C. (2014) Encyclopedia of Social Deviance (2014), USA: SAGE Publications

Fraser, J. (1993). Public accounts: Using verbal protocols to investigate community translators. Applied Linguistics, 14(4), 352-343.

Merriam Webster's online dictionary. (2020, May 13). Retrieved from https://www.merriam-webster.com/ dictionary/community 
Niska, H. (2002). Community Interpreter Training: past, present, future, in Garzone, Giuliana and Viezzi, Maurizio (Eds.) Interpreting in the 21st Century: Challenges and Opportunities (133-144). Amsterdam \& Philadelphia, John Benjamins.

O'Hagan, M. (2011). Community Translation: Translation as a social activity and its possible consequences in the advent of Web 2.0 and beyond. Linguistica Antverpiensia, New Series- Themes in Translation Studies, 10, 11-23.

Schuster, M. \& Olmos, L. (2018). A Question of Communication: The Role of Public Service Interpreting in the Migrant Crisis, The European Legacy, 23(7-8), 733-737. Retrieved from https://cutt.ly/cydeyFk.

Štefková, M., \& Bossaert, B. (2019). Learning from good examples: a comparative analysis of the practices of public service translation and interpreting in Slovakia and Flanders. FITISPos International Journal, 6,168182.

Taibi, M. (2014). Community Interpreting and Translation in the Arab World: Status quo and strategies for chance. Bable, 60(1), 52-69.

Taibi, M. (2011). Public Service Translation.InK. Malmkjaer and K. Windle (Eds.), The Oxford Handbook of Translation Studies (214-15). Oxford: Oxford University Press.

Taibi, M. (2014). Community Interpreting and Translation in the Arab World: Status quo and strategies for chance. Bable, 60(1), 52-69.

Taibi, M.\&Ozolins, U. (2016). Community Translation. London: Bloomsbury Academic.

Tönnies, F. (2004).Community and Society. USA and UK: Transaction Publishers.
Figure 6: Appendix 6

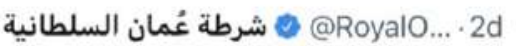

The Royal Oman Police would like to draw the attention of the citizens and residents that the Control and Checkpoints operations between the Governorates of the Sultanate will be stopped as of 6:00 AM, Wednesday.

Q1

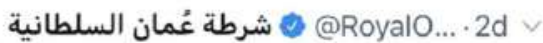
However, the Control and Checkpoint in the Governorate of Muscat will continue its operations according to the previously announced mechanism. The health isolation of Wilayat Muttrah, Wilayat Muscat and the commercial market area in Wilayat Jalan Bani Bu Ali will also continue.

Q2 $2719 \quad \mathrm{Z}_{72}$ 仓

@ @ @ @ @ عُمان السلطانية

The Royal Oman Police calls upon everyone to cooperate and reduce internal movements between the governorates in order to preserve public health and ensure safety for all.

Q8 $8215 \quad$ O64

\section{هُه شرطة عُمان السلطانية}

@RoyalOmanPolice

تسترعي شرطة عمان السلطانية انتباه المواطنين والمقيمين الكرام بأنه سيتم إنهاء نقاط السيطرة والتحكم بين مختلف محافظات السلطنة اعتبارا من الساعة مختا

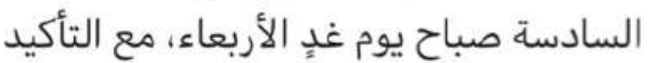
على إبقاء نقاط السيطرة والتحكم على الى معاد محافظة مسقط واستمرار عملها بذات الآلية

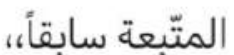

Translate Tweet

10:00 PM · 4/28/20. Twitter for iPhone

578 Retweets 2,076 Likes

๑】 0 个

@RoyalO....2d Replying to @RoyalOmanPolice

وإبقاء العزل الصحي العام على ولايتي مطرح ومسقط وكذلك العزل الصحي العام بمنطقة الصائي السوق التجاري بولاية جعلان بني بولي العاد بلي إلى بلى إشعارِ آخر التجار 